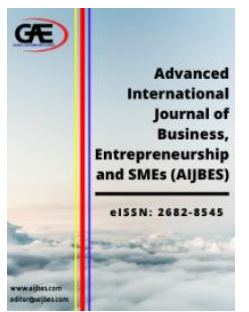

\author{
ADVANCED INTERNATIONAL JOURNAL OF \\ BUSINESS, ENTREPRENEURSHIP AND SMES \\ (AIJBES) \\ www.aijbes.com
}

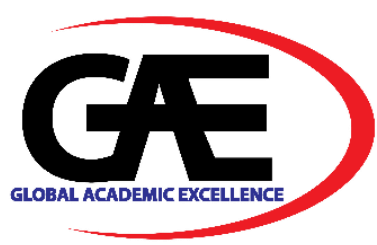

\title{
THE ANALYSIS ON FACTORS INFLUENCING THE USE OF MOBILE PAYMENT SYSTEM AMONG GENERATION Z IN BEKASI CITY
}

\author{
Zxavian Zebadia Simorangkir $^{*}$, Kurnia Fajar Afgani ${ }^{2}$ \\ $1 \quad$ School of Business and Management, Institut Teknologi Bandung \\ Email: zxavian_zebadia@sbm-itb.ac.id \\ 2 School of Business and Management, Institut Teknologi Bandung \\ Email: kurnia.fajar@sbm-itb.ac.id \\ Corresponding Author
}

\section{Article Info:}

Article history:

Received date: 11.07 .2021

Revised date: 20.08 .2021

Accepted date: 12.09 .2021

Published date: 15.09 .2021

\section{To cite this document:}

Simorangkir, Z. Z., \& Afgani, K. F. (2021). The Analysis On Factors Influencing The Use Of Mobile Payment System Among Generation Z In Bekasi City. Advanced International Journal of Business, Entrepreneurship and SMEs, 3 (9), 334-348.

DOI: $10.35631 /$ AIJBES.39022.

This work is licensed under $\mathrm{CC}$ BY 4.0 (c) (2)

\begin{abstract}
:
The topic of the factors that influence the usage of Mobile Payments is not to be overlooked, given the rise in the use of Mobile Payments in recent years. The goal of this study is to identify the factors that have a major impact on users' use of mobile payment instruments. The study was carried out with the help of an online survey questionnaire, which was distributed to 414 people. The impact of performance expectancy, effort expectancy, social influence, trust, and perceived security on the behavioral intention of mobile payment usage was investigated in this study. This study used a quantitative approach, with Generation $\mathrm{Z}$ as the unit of analysis, and the respondents from Bekasi as the target population. Two of the criteria have a significant relationship with the behavioral intention to use the mobile payment instrument, according to the research. Based on the result of this study, it can be seen that perceived security has the most influence on the behavioral intention to use mobile payment, followed by social influence.
\end{abstract}

Keywords:

Mobile Payments, Generation Z, Multiple Linear Regression Method, Quantitative, Online Survey 


\section{Introduction}

\section{Background of the Study}

Every country wishes to be in a stable economic situation. Payment systems are important in today's monetary policy, financial sector, and economic growth (Johnson, 1998). In Indonesia, there are various different types of payment methods. There are two types of payment systems: cash and non-cash (Bank Indonesia, 2019). Paper-based (e.g., checks, transfer forms, and debit notes), card-based (debit and credit cards), and electronic payment instruments make up the non-cash payment system, whilst banknotes and coins make up the cash payment system.

Throughout the year, with the aid of the Central Bank of Indonesia, a number of events have been held to raise public knowledge of Indonesia's electronic payment system. The Indonesian Central Bank launched the Gerakan Nasional Non-Tunai (GNNT) campaign on August 14, 2014. People's payment methods will be changed from cash to electronic payment systems as part of this initiative. The Bank Indonesia event Gerakan National Non-Tunai (GNNT) in 2014 was the first move in encouraging the use of cashless payments in Indonesia. In October 2017, Bank Indonesia introduced the use of electronic money (e-money) as a payment mechanism for usage on the highway, continuing the expansion of cashless events in Indonesia. Bank Indonesia launched Gerbang Pembayaran Nasional (GPN) for debit card interoperability and interconnection in payment systems by the end of 2017. Not only that, but on August 17, 2019, Bank Indonesia established QRIS (QR Code Indonesian Standard) to make a digital payment from a server-based electronic money (e-money), electronic wallet (e-wallet), or mobile banking application. This demonstrated that, following the launch of the Gerakan National Non-Tunai (GNNT) in 2014, Bank Indonesia has continued to raise public awareness of cashless payments.

The rapid technical advancements of the digital era have successfully altered the pattern of life and payment system transactions in society. With the advancement of computers and the expansion of internet access, it is becoming easier to develop more effective payment service systems (Widiyati \& Hasanah, 2020). In addition to changing times and technological advancements, paper money transfers (cash) are becoming less effective, and many people are turning to mobile payment, particularly in cities, because of the cash payment system's flaws, such as the less practical use of currency, the time efficiency, and the criminal risk of cash currency.

One of the alternatives that can be utilized to replace the transaction that occurs in the cash payment system is the mobile payment system. There will be no need to carry cash if you use the mobile payment system. The reason for this is that with the mobile payment system, all of the cash required for a transaction may be simply stored in an account after being topped up in the mobile payment app. Top-ups of mobile payments can be made by going to a store that handles them directly, or via ATM transfer, SMS Banking, Mobile Banking, and other methods. With this in mind, those who wish to conduct transactions using mobile payment need simply bring their smartphone with them.

There are always some elements that influence technology adoption (Patel \& Connolly, 2007). As a technological-based payment instrument, mobile payment has various aspects that influence its acceptance in the public sector (Junadi, 2015). This implies that there are factors 
Volume 3 Issue 9 (September 2021) PP. 334-348 DOI 10.35631/AIJBES.39022

that drive mobile payment adoption in Indonesia. This research would study the relationship between the independent variables such as performance expectancy (PE), effort expectancy (EE), social influence (SI), trust (TR), and perceived security (PS) with the dependent variable behavioral intention (BI) with the Generation $\mathrm{Z}$ as a subject that would be studied, particularly in Bekasi City.

\section{Problem Statement}

Since the Central Bank of Indonesia introduced the Gerakan National Non-Tunai (GNNT) in 2014, the Bank of Indonesia has shown to support Indonesia's cashless journey by building a new payment system to replace the cash payment system. According to the previous debate, it can be inferred that the cash payment system is becoming increasingly destructive to society, and that electronic payment systems, particularly mobile payment systems, can be utilized as a substitute for conducting transactions in the digital era.

Given that mobile payment usage in Indonesia is on the rise, it would be worthwhile to investigate the elements that influence people's willingness to utilize the system. By understanding the reasons, they can be taken into account as a source of concern in order to raise the existing level of mobile payment usage in Bekasi. The variables can also be used to determine the most influential aspects, allowing the mobile payment provider to focus on improving the mobile payment system based on the elements that impact public willingness to utilize mobile payments. The factors can also be used to discover the most influential aspects so that the mobile payment provider can focus on improving the mobile payment system based on the elements that influence people's willingness to utilize mobile payments.

\section{The Objective of The Study}

1. To determine the elements that influence Generation Z's Behavioral intention (BI) to utilize mobile payments in Bekasi.

2. To determine the most influential factor influencing Generation Z's Behavioral intention (BI) to utilize mobile payments in Bekasi.

\section{Research Questions}

1. What are the factors that influence Generation Z's Behavioral intention (BI) to utilize mobile payments in Bekasi?

2. What is the most important aspect that determines Generation Z's Behavioral intention (BI) to utilize mobile payments in Bekasi?

\section{Literature Review}

\section{Mobile Payment}

A mobile payment system (Junadi, 2015) is a type of payment system that employs mobile devices or smartphones to exchange monetary value transactions and is run by mobile network carriers. People who wished to utilize it only had to register their mobile number and account with the mobile payment app (Yan \& Yang, 2014). Furthermore, mobile payment users are increasing from young to the elderly due to the convenience of financial transactions via cell phones as a payment medium (Liébana-Cabanillas, Sánchez-Fernández \& Muoz-Leiva, 2014). 
Volume 3 Issue 9 (September 2021) PP. 334-348

DOI 10.35631/AIJBES.39022

Mobile payments come in a number of forms, but the technologies used to transfer them can be split into two categories: long-distance and near-distance payments. Customers who wish to make long-distance payments must first join up for the service, which usually entails downloading an app, and then use it to pay for an item using their mobile device. Customers can put money into prepaid accounts or take out loans from their bank accounts. Payment service companies like Google and PayPal, for example, are utilizing a cloud-based longdistance solution to mobile payments in businesses. Near-distance payments, on the other hand, require the consumer to present their smartphone, tablet, or electronic device at a payment terminal while holding it within a few centimetres of the terminal to complete the transaction.

Mobile payment can be classified into three categories: mobile commerce, mobile acceptance, and mobile wallet (Morgan, 2013). Mobile commerce is one of the e-commerce categories (Coursaris \& Hassanein, 2002). Mobile commerce is carried out through the use of smartphones, which allow customers to execute digital transactions directly in their hands, anywhere, utilizing wireless technology. Mobile payment acceptance, on the other hand, is the process of integrating electronic devices (such as smartphones, tablets, and other mobile devices) into the system by adding temporary or permanent hardware that allows retailers to take card-based payments. For example, a store device like a magnetic stripe reader might be connected to a customer's smartphone via an audio jack to serve as an additional barcode scanner or to process debit or credit card transactions. Finally, a mobile wallet is a service that allows customers to make payments without utilizing their credit or debit cards. According to Taylor (2016), there are a range of mobile wallet manufacturers, some of which rely on proximity technologies like close field communications that may be put in cell phones or stickers, and others that are cloud-based.

The mobile payment service program can be used to pay for non-cash products and services once it has been registered. Top-ups are available in person at the outlet, via an ATM switch, SMS Banking, Mobile Banking, and other methods. QR codes, One-Time Passwords (OTPs), and Near-Field Communication (NFC) are the three most used platforms for mobile payments (NFC). Currently in Indonesia, there are several mobile payment providers such as GOPAY, OVO, LinkAja, Dana, iSaku, Doku, Sakuku, PayTren and True.

\section{Generation $Z$}

Generation Z a generation born between 1995 and 2010 (Oblinger \& Oblinger, (2005), grew up in a society where crime and environmental crises were widespread. They have witnessed the widespread use of mobile devices and digital technologies, such as the Internet, social media, and websites. Characters in Generation Z include techies, people who are internationally connected (in a virtual world), people who are sharper and more nimble, and people who respect many cultures (Grail Research, 2011).

\section{Performance Expectancy}

The degree to which a person believes that incorporating technology can help him or her improve job results is referred to as performance expectation (Venkatesh et al., 2003). Individuals are more likely to adopt and embrace new technology if they believe it will be more beneficial and useful in their daily lives (Davis, Bagozzi \& Warshaw, 1989). When it comes to technology adoption, the ease with which consumers feel at ease when utilizing technology raises expectations for the technology's performance (Zhou, Lu, \& Wang, 2010). 


\section{Performance Expectancy towards Behavioral Intention}

Performance Expectancy is described as the degree to which a person believes that implementing technology can help him or her improve job results (Venkatesh et al., 2003). In addition, Performance Expectancy can also refers to a person's confidence that such developments can lead to positive outcomes (Casey \& Wilson-Evered, 2012). The factor was formed from the merging of five different factors such as Relative Advantages from DIT (Diffusion Innovation Theory), Perceived Usefulness from TAM (Technology Acceptance Model), External Motivation from Motivational Model, Job fit from MPCU (Model of PC Utilization), and outcome expectations from SCT (Social Cognitive Theory). Based on the previous study, the research showed that Performance Expectancy has a significant relationship towards Behavioral Intention to use technology (Venkatesh et al., 2003; Ghalandari, 2012; Rosnidah et. al, 2018; Alalwan, Dwivedi \& Rana, 2017; \& Zhou et al., 2010).

\section{Effort Expectancy}

Effort expectancy is the apparent ease with which the system can be used (Venkatesh et al., 2003). When people perceive that utilizing technology is simple, they have higher expectations that it will perform well. Similar constructs of Effort Expectancy exist in other models, such as perceived ease of use (technology acceptance model) and complexity (PC utilization model and innovation theory) (Ghalandari, 2012). Furthermore, people's desire to accept a new system is influenced not just by how well the system is regarded, but also by how easy it is to use and how little effort is required (Davis, Bagozzi \& Warshaw, 1989).

\section{Effort Expectancy towards Behavioral Intention}

The degree to which people believe that adopting new technology will allow them to put less effort into their work is known as Effort Expectancy (Venkatesh et al., 2003). When people perceive that utilizing technology is simple, they have higher expectations that it will perform well. Ease of Use from DIT (Diffusion Innovation Theory), Perceived of Usefulness from TAM (Technology Acceptance Model), and Complexity from MPCU (Model of PC Utilization) were combined to create this element (Venkatesh et al., 2003). Effort Expectancy has been demonstrated to influence customers' willingness to use mobile payment in previous studies (Venkatesh et al., 2003; Ghalandari, 2012; Rosnidah et. al, 2018; \& Alalwan, Dwivedi \& Rana, 2017). As a result, given the unique nature of mobile payment, which necessitates a certain level of competence and skill, customers' willingness to use such technology may be determined by Effort Expectancy.

\section{Social Influence}

The degree to which an individual believes that other people are relevant to him/her in adopting new technologies is referred to as social influence on the UTAUT model (Venkatesh et al., 2003). Furthermore, information and assistance provided by persons in the immediate vicinity of clients may play a significant role in increasing customer awareness and enthusiasm to use technology (Alalwan, Dwived \& Williams, 2016). In terms of mobile banking, The impact of a customer's social environment, such as reference groups, family, opinionated leaders, friends, and colleagues, on their decision to use mobile banking is known as social influence (Zhou, Lu, \& Wang, 2010). 


\section{Social Influence towards Behavioral Intention}

The degree to which individuals believe it is necessary for others to believe that they should utilize the same technology is referred to as social influence (Venkatesh et al., 2003). Subjective Norms from TRA (Theory of Reasoned Action), TPB (Theory of Planned Behavior), and C-TAM-TPB (Combined TAM and TPB), Image from DIT (Diffusion of Innovation Theory), and Social Factors from MPCU (Model of PC Utilization) are all constructs of Social Influence in various models and theories (Venkatesh et al., 2003). Prior study has shown that social influence has an impact on customers' propensity to use online banking channels, hence it was chosen as a crucial factor of behavioral intention (Ghalandari, 2012; Rosnidah et. al, 2018; \& Zhou, Lu, \& Wang, 2010. As a result, one of the factors determining the extent of mobile payment uptake will be social influence.

\section{Trust}

According to Gefen, Karahanna, and Straub (2003), Consumer trust in Mobile banking can be operationalized as the accumulation of customer values of honesty, benevolence, and capacity that could improve customer willingness to rely on Mobile banking to complete financial transactions. On the research by Alalwan, Dwivedi and Rana (2017), trust was found to be the most significant factor predicting the customers' intention to adopt Mobile banking. According to the research by Perkins and Annan (2013), as a result, trust is considered a significant construct in the study's investigation of students' intentions to use the e-payment system.

\section{Trust Towards Behavioral Intention}

Consumer trust in Mobile banking may be defined as the total of a customer's values of honesty, kindness, and capability, all of which could increase a customer's readiness to use Mobile banking to conduct financial transactions (Gefen, Karahanna \& Straub, 2003). Trust has been thoroughly researched and found to be a key element in determining consumer views and intentions toward mobile payments (Alalwan, Dwivedi \& Rana, 2017; Perkins \& Annan, 2013; and Salloum \& Al Emran, 2018). According to a study, trust is the most important factor in determining customers' willingness to use mobile banking (Alalwan, Dwivedi \& Rana, 2017). Furthermore, according to the findings, trust has a significant relationship with performance expectations. As a result, in the study's analysis of students' intents to use the e-payment system, trust is regarded a crucial component (Perkins \& Annan, 2013). As a result, trust is expected to have a direct impact on customers' willingness to use Mobile Payment services in this study.

\section{Perceived Security}

In order to prevent data and network issues, security is a collection of protocols, processes, and computer programs that authenticate the source of information and ensure its confidentiality and privacy (Huang \& Cheng, 2012). Perceived Security becomes one of the factors that are being tested towards the user's behavioral intention to use electronic payment (Junadi, 2015). When it comes to electronic payment instruments, security refers to both the individual's understanding of the payment method's worthiness and all of the instrument's data transmission and storage mechanisms (Kolsaker, 2002). On the other hand, Perceived protection is described as the subjective likelihood that individuals believe their personal information will not be accessed and misused by untrustworthy parties (Flavian \& Guinaliu, 2006). 


\section{Perceived Security towards Behavioral Intention}

In preventing data and network issues, security is a collection of protocols, processes, and computer programs that authenticate the source of information and ensure its confidentiality and privacy (Huang \& Cheng, 2012). When it comes to electronic payment instruments, security refers to both the individual's understanding of the payment method's worthiness and all of the instrument's data transmission and storage mechanisms (Kolsaker, 2002). On the other hand, Perceived protection is described as the subjective likelihood that individuals believe their personal information will not be accessed and misused by untrustworthy parties (Flavian \& Guinaliu, 2006). There are some of the previous studies that have been using Security as a factor to examine users' intention to use electronic payment instruments (Perkins \& Annan, 2013; Ghorban, Jajaee \& Tahernead, 2011; \& Susanto et al., 2013). Thus, based on the previous research that has been conducted, Perceived Security is supposed to have a direct effect on the customers' intention to use mobile payment.

\section{Behavioral Intention}

In the prior literature, Behavioral intention has been consistently found to play a major role in deciding how new systems are used and accepted (Ajzen, 1991). Behavioral intention refers to a person's willingness to engage in such behaviors and is believed to be a spontaneous action (Lu, Huang \& Lo, 2010). In reference to technology, Behavioral Intention can be defined as the desire to keep using technology (Davis, Bagozzi \& Warshaw, 1989).

\section{Methodology}

This study would be carried out in Bekasi, West Java, Indonesia. The study would be using a questionnaire that serves as an instrument to collect the data from the respondents.

\section{Population and Sample}

The population for the study would be determined based on the Slovin Formula. Based on the formula, $\mathrm{n}=\mathrm{N} /\left(1+\mathrm{N}^{*} \mathrm{e}^{\wedge} 2\right)$. Where $\mathrm{N}=2,543,676$ (Population) and $\mathrm{e}=.05$. Hence, 2,543,676 $/\left(1+2,543,676^{*} 0.05^{\wedge} 2\right) \approx 400$. As a result, the computation resulting from the questionnaire that required to be circulated indicated that 400 valid questionnaires from Generation $\mathrm{Z}$ would need to be delivered in Bekasi City.

\section{Procedure and Data Collection}

The questionnaires were carried out from March to June 2021. By distributing the questionnaire via social media, as well as the word of mouth, 414 respondents answered the questionnaire with 5 respondents that answers that they did not use the mobile payment. In conclusion, 409 valid answers are collected.

\section{Instrument Used for Data Collection}

The sections of the questionnaire would be divided into seven sections. The first sections would be the respondent's profile where the respondents filled the information such as their gender, age range, phone number, confirmatory questions and type of mobile payment used. The next six sections are the sections in which the respondents filled their answers regarding the factors in using mobile payment. In answering the questionnaire, the answers are made based on the '6' points Likert Scale, 1 Strongly Disagree, 2 Disagree, 3 Quite Disagree, 4 Quite Agree, 5 Agree, 6 Strongly Agree. 


\section{Data Analysis Techniques}

The researcher will employ a statistical technique in this investigation, beginning with a validity and reliability test. The researcher will utilize Pearson Correlation with a confidence level of $95 \%$ to conduct the validity test. Cronbach's alpha was used to determine the measure's reliability. A coefficient greater than or equal to 0.5 is generally considered acceptable and also a good sign of constructive reliability.

In addition, the statistical technique will employ Multi Linear Regression to determine the correlations between two or more variables with cause-and-effect relationships, as well as to generate topic predictions based on the relationship. It is employed in this study since there are numerous independent factors being examined toward one dependent variable. This technique is used to see if there are any significant correlations between the independent and dependent variables.

\section{Results}

\section{Validity and Reliability Test}

The validity and reliability of the data collected from the questionnaire will be tested using the validity and reliability tests to ensure that the data collected is both valid and reliable. Because 414 respondents' responses were gathered, and 5 respondents did not use mobile payment, the validity and reliability test would be conducted on 409 respondents in this study.

Table 1: Validity Test of the Variables

\begin{tabular}{l|l|l|l}
$\begin{array}{l}\text { Factors } \\
\text { Terms }\end{array}$ & R Count & \multicolumn{1}{c}{$\begin{array}{l}R \\
\text { Table }\end{array}$} \\
\hline PE1 & 0.506 & 0.098 & Results \\
PE2 & 0.529 & 0.098 & Valid \\
PE3 & 0.501 & 0.098 & Valid \\
PE4 & 0.612 & 0.098 & Valid \\
EE1 & 0.542 & 0.098 & Valid \\
EE2 & 0.566 & 0.098 & Valid \\
EE3 & 0.571 & 0.098 & Valid \\
EE4 & 0.595 & 0.098 & Valid \\
SI1 & 0.552 & 0.098 & Valid \\
SI2 & 0.594 & 0.098 & Valid \\
SI3 & 0.538 & 0.098 & Valid \\
SI4 & 0.534 & 0.098 & Valid \\
TR1 & 0.692 & 0.098 & Valid \\
TR2 & 0.701 & 0.098 & Valid \\
TR3 & 0.661 & 0.098 & Valid
\end{tabular}




\begin{tabular}{l|ll|c} 
& & & DOI 10.35631/AIJ \\
TR4 & 0.648 & 0.098 & Valid \\
PS1 & 0.694 & 0.098 & Valid \\
PS2 & 0.663 & 0.098 & Valid \\
PS3 & 0.502 & 0.098 & Valid \\
PS4 & 0.597 & 0.098 & Valid \\
PS5 & 0.713 & 0.098 & Valid \\
BI1 & 0.423 & 0.098 & Valid \\
\hline BI2 & 0.432 & 0.098 & Valid
\end{tabular}

Source: Authors Validity Test via SPSS

Table 2: Reliability Test of the Variables

\begin{tabular}{|l|c|c|}
\hline Items & No of sub-items & Cronbach's Alpha \\
\hline Performance Expectancy & 4 & .762 \\
\hline Effort Expectancy & 4 & .843 \\
\hline Social Influence & 4 & .817 \\
\hline Trust & 4 & .854 \\
\hline Perceived Security & 5 & .824 \\
\hline Behavioral Intention & 2 & .840 \\
\hline
\end{tabular}

Source: Authors Validity Test via SPSS

According to the result of the validity as well as the reliability for the data, the questionnaire was tested as valid and reliable and was proven to be dependable. With this in mind, the questionnaire might be distributed to respondents in order to collect data for a much broader research project.

\section{The Variables that Influence the Behavioral Intention to Use Mobile Payment Instruments}

There are five factors that influence the Behavioral Intention to use mobile payment among Generation Z in Bekasi City: Performance Expectancy, Effort Expectancy, Social Influence, Trust and Perceived Security. Those are the five variables that will act as the independent variables. By studying the factors, this research can be used to make the recommendations needed to boost and control the use of mobile payment among Generation $\mathrm{Z}$ in Bekasi City. With that in mind, the conceptual framework of this study would be as follows. 


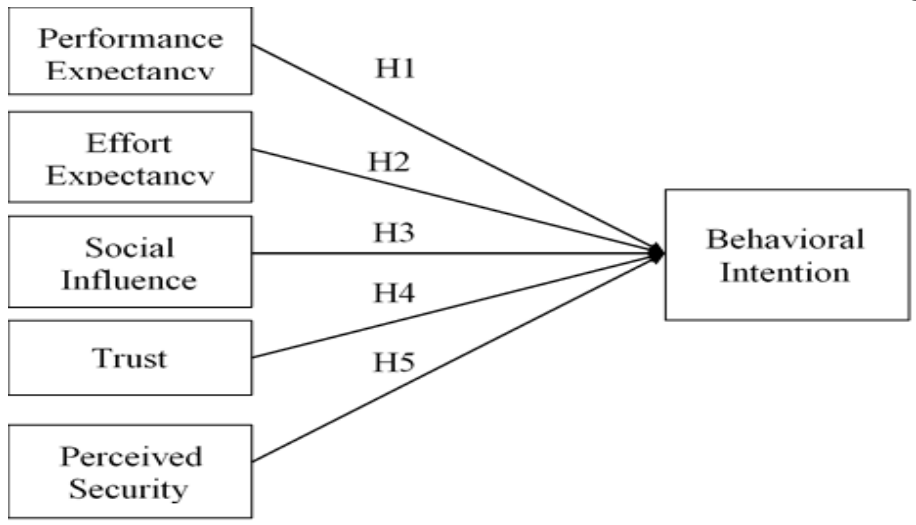

Source: Author's interpretation

Figure 1: Conceptual Framework

First of all, this research would measure the dependent variables' response frequency. There are two questions for the dependent variable. By using the Likert Scale, all questions would be answered by using the six likert scale with one indicating Strongly Disagree and five indicating Strongly Agree. This research use six likert scale because the 6 likert scale is chosen to avoid having the middle choice, which may create the respondents bias to choose it as the safe selection (Dhar \& Simonson, 2003). The Behavioral Intention results from the 409 respondents would be as follows.

Table 3: Dependent Variable - Behavioral Intention

\begin{tabular}{|c|c|c|c|c|c|c|c|c|c|}
\hline \multirow{2}{*}{ No } & \multirow{2}{*}{ Label } & \multicolumn{6}{|c|}{ Response Frequency } & \multirow{2}{*}{ Total } & \multirow{2}{*}{ Mean } \\
\hline & & 1 & 2 & 3 & 4 & 5 & 6 & & \\
\hline \multirow{2}{*}{1} & \multirow{2}{*}{ PE1 } & 0 & 2 & 29 & 140 & 185 & 53 & 409 & \multirow{2}{*}{4.63} \\
\hline & & $0.00 \%$ & $0.48 \%$ & $7.09 \%$ & $34.22 \%$ & $45.23 \%$ & $12.95 \%$ & $100.00 \%$ & \\
\hline \multirow{2}{*}{2} & \multirow{2}{*}{ PE2 } & 0 & 5 & 30 & 116 & 189 & 69 & 409 & \multirow{2}{*}{4.70} \\
\hline & & $0.00 \%$ & $1.22 \%$ & $7.33 \%$ & $28.36 \%$ & $46.21 \%$ & $16.87 \%$ & $100.00 \%$ & \\
\hline & & & otal Me & of the & haviora & Intentior & ariable & & 4.66 \\
\hline
\end{tabular}

Table 3 represents the result of respondents' Behavioral Intention to use mobile payment. Based on the table, it can be seen that the total responses for all item in the questionnaires are 409 , indicates 5 people are indeed did not use mobile payment but fills the questionnaire. The mean score for the item questionnaires is ranging from 4.63 to 4.70 , with the total mean score of 4.66 from the maximum score of 6 . This result indicates that respondent is agree that they have plans on using mobile payment.

In addition, the multiple linear regression analysis is used in this study to determine the link between the dependent variable and factors impacting more than one independent variable. Its goal is to determine the strength of the association between the dependent variable and five independent variables. Because this study uses a 95 percent level of confidence, all of the analyses in this multiple linear regression approach are done with an alpha of 0.05. The outcome of the analysis is shown in Table 2 below. 
Volume 3 Issue 9 (September 2021) PP. 334-348 DOI 10.35631/AIJBES.39022

Table 4: Statistical Analysis - Multiple Linear Regression

\begin{tabular}{|c|c|c|c|c|c|}
\hline \multirow{2}{*}{ Model } & \multicolumn{2}{|c|}{$\begin{array}{c}\text { Unstandardized } \\
\text { Coefficient }\end{array}$} & $\begin{array}{c}\text { Standardized } \\
\text { Coefficient }\end{array}$ & \multirow{2}{*}{ t } & \multirow{2}{*}{ Sig. } \\
\cline { 2 - 4 } & B & Std. Error & B & & \\
\hline (Constant) & 3.885 & .937 & & 4.148 & .000 \\
\hline PE & .047 & .054 & .054 & .871 & .384 \\
\hline EE & .038 & .041 & .056 & .937 & .349 \\
\hline SI & .090 & .024 & .194 & 3.740 & .000 \\
\hline TR & -.114 & .042 & -.201 & -2.734 & .007 \\
\hline PS & .168 & .033 & .355 & 5.033 & .000 \\
\hline
\end{tabular}

Source: Author's interpretation

By using the multiple linear regression equation, the equation model would be as follows.

$$
\mathrm{Y}=3.885+.047 \mathrm{X} 1+.038 \mathrm{X} 2+.090 \mathrm{X} 3-.114 \mathrm{X} 4+.168 \mathrm{X} 5
$$

Based on this equation, the Behavioral Intention to use mobile payment instrument would have a value of 3.885 except for constant when all independent variable have a zero value. Performance Expectancy has a value of 0.047 which means that when the Performance Expectancy increases by one unit, the Behavioral Intention to use mobile payment will increase by 0.047 units. Nexr, the Effort Expectancy with a value of 0.038 meaning that when the Effort Expectancy increases by one unit, the Behavioral Intention to use mobile payment will increase by 0.038 units. After that is the Social Influence, with a total value of 0.090 meaning that when Social Influence increases by one unit, the Behavioral Intention to use mobile payment will increase by 0.090 units. Meanwhile, the result of the Trust value is -0.114 , meaning that Behavioral Intention to use mobile payment will decrease by 0.114 units if the Trust value increases by one unit. Lastly, Perceived Security's value is 0.168 which indicates that if the Perceived Security value increases by one unit, Behavioral Intention to use mobile payment will increase by 0.168 .

The coefficient of determination from the regression analysis will then be used in this study to see how well the model can describe the variance of the dependent variable. The following are the findings of this investigation.

Table 5: Statistical Analysis - Coefficient of Determination

\begin{tabular}{|c|c|c|c|c|}
\hline Model & R & R Square & $\begin{array}{c}\text { Adjusted R } \\
\text { Square }\end{array}$ & $\begin{array}{c}\text { Std. Error of the } \\
\text { Estimate }\end{array}$ \\
\hline 1 & .394 & .156 & .145 & 1.454 \\
\hline
\end{tabular}

Source: Author's interpretation

The amount of variance explained by the independent variable in the dependent variable is calculated using the coefficient of determination ( $\mathrm{R}$ square) in the model summary. The $\mathrm{R}$ square value between the independent variables (Performance Expectancy, Effort Expectancy, Social Influence, Trust and Perceived Security) and the dependent variable (Behavioral Intention) is 15.6 percent, according to table 3 above. This suggests that the independent factors only account for 15.6 percent of the Behavioral Intention inference, meaning that the other variables impact the Behavioral Intention 84.4 percent more than the independent variables. 
Next, this research would do both the T test and P-value test to figure out the influence of each independent variables towards the dependent variable. The result would show which independent variables that has significant relationship towards the dependent variable. If the significant value is less than 0.05 , the hypothesis of this research would be accepted as well as the when the significant value is more than 0.05 , the hypothesis would be rejected. In addition, the $T$ value can also be used to determine the relationship of the variables by depending on the $T$ value of the variables which must be greater than the $T$ Table value. The $T$ table value of this research would be $+/-1.152$. The findings would be as follow.

Table 6: Statistical Analysis - T Test and P-Value Test

\begin{tabular}{|c|c|c|c|}
\hline Hypothesis & Sig. Value & t Value & Result \\
\hline $\begin{array}{c}\text { Performance Expectancy (PE) has } \\
\text { significant correlation with } \\
\begin{array}{c}\text { Behavioral Intention (BI) to use } \\
\text { mobile payment instruments for } \\
\text { generation Z in Bekasi city }\end{array}\end{array}$ & .384 & .871 & Rejected \\
\hline $\begin{array}{c}\text { Effort Expectancy (EE) has } \\
\text { significant correlation with } \\
\text { Behavioral Intention (BI) to use } \\
\text { mobile payment instruments for } \\
\text { generation Z in Bekasi city }\end{array}$ & .349 & .937 & Rejected \\
\hline $\begin{array}{c}\text { Social Influence (SI) has significant } \\
\text { correlation with Behavioral } \\
\text { Intention (BI) to use mobile } \\
\text { payment instruments for generation } \\
\text { Z in Bekasi city }\end{array}$ & .000 & 3.740 & Accepted \\
\hline $\begin{array}{c}\text { Trust (TR) has significant } \\
\text { correlation with Behavioral } \\
\text { Intention (BI) to use mobile } \\
\text { payment instruments for generation } \\
\text { Z in Bekasi city }\end{array}$ & .007 & -2.734 & Rejected \\
\hline $\begin{array}{c}\text { Perceived Security (PS) has a } \\
\text { significant correlation with } \\
\text { Behavioral Intention to use mobile } \\
\text { payment instruments among } \\
\text { generation Z in Bekasi City }\end{array}$ & .000 & 5.033 & Accepted \\
\hline
\end{tabular}

Source: Author's interpretation

Lastly, this research would determine the most influential factor that influence the behavioural intention to use mobile payment instrument. To determine the most influential factor from the significant factor, this research would see from the unstandardized beta value from the table 4 . From the table, the unstandardized beta value of Social Influence is 0.090 and the value from Perceived Security is 0.168 . This means that the most influential factor from the framework is the Perceived Security. 


\section{Discussion}

The findings shows that the some of the variables in the framework are indeed influence the Behavioral Intention to use mobile payment among Generation $\mathrm{Z}$ in Bekasi City. From all the variables, the social influence and perceived security are proven to influence the behavioral intention to use mobile payment instrument among Generation $\mathrm{Z}$ in Bekasi City. In addition, the most influential variable would be the perceived security.

\section{Conclusion}

This study represents the respondent's response to several factors that may influence the behavioural intention to use mobile payment instrument. The factors would be Performance Expectancy, Effort Expectancy, Social Influence, Trust and Perceived Security. Since the accepted hypotheses would come down into three hypotheses, the framework of this study would be modified to be Social Influence, Trust and Perceived Security that influence the Behavioural Intention to use mobile payment instrument. In the process of collecting the data, this research had use the questionnaires to be distributed and analyse the data further with statistical test. This research would help especially mobile payment provider, mobile payment user, as well as government to figure out the factors the influence the use of mobile payment instrument.

The objectives of this study were to identify the factors that have significant relationship towards the Behavioral Intention as well as to figure the most influential factor in from the framework that influence the Behavioral Intention to use mobile payment instrument in Bekasi city among Generation $\mathrm{Z}$. According to the findings of this study, Social Influence and Perceived Security all have a significant relationship. On the other hand, Performance Expectancy, Effort Expectancy and Trust variable does not have any significant relationship towards the Behavioral Intention. For the most influential factor, the order of the most influential factor would be Perceived Security and Social Influence. With that in mind, the most influential factor from this study would be the Perceived Security.

\section{Recommendation}

This study offers some recommendations for the electronic payment instrument provider, the user, and the government, based on the research implications discussed in the previous section.

1. For the electronic payment provider, the first recommendation would be to make sure that the provider to make sure that the platform could provide the information that ensures the users that their data as well as their privacy that is listed on the main headquarters in the mobile payment data is highly safe and secure.l

2. The next is for the promotion of the mobile payment instrument by focusing on the factors that influence the behavioral intention, the perceived security and social influence, to be focused on.

3. For the government, since the government makes the regulations, the government can focus on the factors that influence the behavioral intention on making regulations for the using or developing mobile payment.

4. For the user, the user can make use of this research to focus on the factors that influence the behavioral intention in using mobile payment to choose the mobile payment wo use. 


\section{References}

Ajzen, I., 1991. The theory of planned behavior. Organizational behavior and human decision processes, 50(2), 179-211.

Alalwan, A., Dwivedi, Y. \& Williams, M. (2016). Customers' Intention and Adoption of Telebanking in Jordan. Information Systems Management, 33(2), pp.154-178.

Alalwan, A., Dwivedi, Y. \& Rana, N. (2017). Factors influencing adoption of mobile banking by Jordanian bank customers: Extending UTAUT2 with trust. International Journal of Information Management, 37(3), pp.99-110.

Bank Indonesia. (2019). Sistem Pembayaran di Indonesia. Retrieved from https://www.bi.go.id/id/sistem-pembayaran/di-indonesia/Contents/Default.aspx

Casey, T. \& Wilson-Evered, E. (2012). Predicting uptake of technology innovations in online family dispute resolution services: An application and extension of the UTAUT. Computers in Human Behavior, 28(6), pp.2034-2045.

Coursaris, C. \& Hassanein, K. (2002). Understanding m-commerce. Quarterly Journal of Electronic Commerce, 3(3), pp.247-271

Davis, F., Bagozzi, R. \& Warshaw, P. (1989). User Acceptance of Computer Technology: A Comparison of Two Theoretical Models. Management Science, 35(8), pp.982-1003.

Dhar, R. \& Simonson, I. (2003). The Effect of Forced Choice on Choice. Journal of Marketing Research, 40(2), pp.146-160.

Flavián, C. and Guinalíu, M. (2006). Consumer trust, perceived security and privacy policy. Industrial Management \& Data Systems, 106(5), pp.601-620.

Ghalandari, K. (2012). The Effect of Performance Expectancy, Effort Expectancy, Social Influence and Facilitating Conditions on Acceptance of E-Banking Services in Iran: the Moderating Role of Age and Gender. Middle-East Journal of Scientific Research, 12(6), 801-807.

Ghorban, Z. S., Jajaee, S. M. \& Tahernejad, H. (2011). The Study of Customer's Perceptions of Security in E-Payment System in Iran. In International Conference on Business and Economic Research (2nd) (pp. 891-910).Grail Research. (2011). Insights and Observations about Generation Z: Consumers of Tomorrow.

Huang, E. \& Cheng, F. (2012). Online Security Cues and E-Payment Continuance Intention. International Journal of E-Entrepreneurship and Innovation, 3(1), pp.42-58.

Johnson, O. E. G. (1998). Payment systems, monetary policy, and the role of the central bank. Washington, DC. International Monetary Fund.

Junadi, S. (2015). A model of factors influencing consumer's intention to use e payment system in Indonesia.

Kolsaker, A. \& Payne, C. (2002). Engendering trust in e-commerce: a study of gender-based concerns. Marketing Intelligence \& Planning, 20(4), pp.206-214.

Liébana-Cabanillas, F., Sánchez-Fernández, J. \& Muñoz-Leiva, F. (2014). Antecedents of the adoption of the new mobile payment systems: The moderating effect of age. Computers in Human Behavior, 35, pp.464-478.

Lu, C. T., Huang, S. Y. \& Lo, P. Y. (2010). An empirical study of on-line tax filing acceptance model: Integrating TAM and TPB. African Journal of Business Management, 4(5), pp.800-810.

Morgan, J. P. (2013). Insights from J.P. Morgan. Morgan, J.P. Available at: www.jpmorgan.com [Accessed March 16, 2021].

Oblinger, D., \& Oblinger, J. (2005). Is it age or IT: First steps toward understanding the next generation. Educating the net generation, 2(1-2), 20. 
Patel, H., \& Connolly, R. (2007). Factors Influencing Technology Adoption: A Review. Information Management in the Networked Economy: Issues \& Solutions.

Perkins, E. D. \& Annan, J. (2013). Factors affecting the adoption of online banking in Ghana: implications for bank managers. International Journal of Business and Social Research (IJBSR), 3(6), pp.94-108.

Rosnidah, I., Muna, A., Musyaffi, A. M., \& Siregar, N. F. (2018). Critical Factor of Mobile Payment Acceptance in Millennial Generation: Study on the UTAUT model.

Susanto, A., Lee, H., Zo, H. \& Ciganek, A. (2013). User acceptance of Internet banking in Indonesia: initial trust formation. Information Development, 29(4), pp.309-322.

Venkatesh, V., Morris, M. G., Davis, G. B., \& Davis, F. D. (2003). User acceptance of information technology: Toward a unified view. MIS quarterly, 425-478.

Widiyati, D. \& Hasanah, N. (2020). FACTORS AFFECTING THE USE OF E-MONEY (STUDY ON E-MONEY USER IN CITY OF SOUTH TANGERANG).

Yan, H., \& Yang, Z. (2014). An Empirical Examination of User Adoption Mobile Payment. Int. Conf. Manag. e-Commerce e-Government, pp. 156-162, 2014.

Zhou, T., Lu, Y. \& Wang, B. (2010). Integrating TTF and UTAUT to explain mobile banking user adoption. Computers in Human Behavior, 26(4), pp.760-767. 